\title{
SICKNESS, CHANGE OF RESIDENCE, AND DEATH* \\ II. SICKNESS REPORTED IN HOUSEHOLD SURVEYS AND SUBSEQUENT MORTALITY
}

\author{
BY \\ DONOVAN J. THOMPSON AND ANTONIO CIOCCO \\ Department of Biostatics, Graduate School of Public Health, University of Pittsburgh, Pa.
}

In the first paper of this series (Thompson and Ciocco, 1958) we noted that those persons who reported some illness in a morbidity survey conducted on a sample of households in the Pittsburgh Arsenal District in 1951 had died by 1956 at a higher rate than persons who did not report illness in 1951. Similarly, persons reported to be affected by smog in Donora in 1948 experienced a higher mortality between 1948 and 1957 than persons who stated in 1948 that they were not affected. These findings raise at least three questions:

(1) Is the observed higher mortality of the sick group due to a higher incidence of a specific cause of death?

(2) Is this higher mortality related to certain reported sickness?

(3) Are certain sicknesses associated with certain causes of death?

In this paper we present data in part answer to these questions.

\section{Material and Method}

A detailed description of the sources of the data analysed in this paper may be found in the paper cited above. In summary, the Donora data relate to a sample of 2,712 persons 21 years of age and over who were studied in 1948 to investigate the sickness effects of the smog episode of October of that year. This group was surveyed again in 1957 to determine, among other things, the mortality in the intervening 8 years. The first survey of the Arsenal District in 1951 provided illness information on 6,305 persons 21 years of age and over. Mortality to July, 1956, among this group of persons has been determined by a variety of methods.

* This work was supported in part by a research contract with the Air Pollution Medical Program, Public Health Service, U.S. Department of Health, Education, and Welfare.
The definitions of illness at the time of the initial survey in the two areas differed. In the 1948 Donora survey all persons answering yes to the question, "were you affected by smog of October 28-31?" are classified under "acute illness". The "all illness" category includes the "acute illness" group plus persons who, while not affected by the smog, answered $y e s$ to questions concerning the prevalence of certain chronic illnesses such as asthma, heart disease, chronic bronchitis, tuberculosis, and sinusitis. The "ill" group in the Arsenal study includes all persons who responded positively to general questions re garding sickness in the month before the survey, hospitalization in the year preceding the survey, or: injury or accidents for which medical care was sought during this period.

\section{RESULTS}

(1) Sickness and Major Causes of Death.-Table I (opposite) shows the percentages of persons who died from neoplasms, vascular lesions of the central nervous system, cardiovascular diseases, and other or unspecified causes between 1948 and 1957 for the Donora sample, and 1951 and 1956 for the Arsenal sample.

In the Donora sample the mortality rates of the "ill" group are not consistently higher than those of the "not-ill" group for any cause of death.

Mortality from cardiovascular diseases is higher for the ill males than the not-ill males in all four age groups, but they are higher in the ill females than the not-ill females in only three of the four age groups.

Mortality from vascular lesions of the central nervous system is higher among the ill females than the not-ill females in the three age groups in which it occurred, but is lower among the ill males than among the not-ill males in the two age groups in which it occurred. 
TABLE I

RELATIONSHIP OF ILLNESS EXPERIENCE REPORTED TO MORTALITY RATE PER 100, BY CAUSE, SEX, AND AGE

\begin{tabular}{|c|c|c|c|c|c|c|c|c|c|c|}
\hline \multirow[b]{2}{*}{ Place } & \multirow{2}{*}{$\begin{array}{c}\text { Period } \\
\text { of } \\
\text { Mortality }\end{array}$} & \multirow{2}{*}{$\begin{array}{c}\text { Year } \\
\text { of } \\
\text { Illness } \\
\text { Experi- } \\
\text { ence }\end{array}$} & \multirow[b]{2}{*}{ Sex } & \multirow[b]{2}{*}{$\begin{array}{l}\text { Age } \\
\text { (yrs) }\end{array}$} & \multirow[b]{2}{*}{$\begin{array}{l}\text { Illness } \\
\text { Status }\end{array}$} & \multirow{2}{*}{$\begin{array}{l}\text { Number } \\
\text { of } \\
\text { Persons }\end{array}$} & \multicolumn{4}{|c|}{ Cause of Death } \\
\hline & & & & & & & $\begin{array}{l}\text { Neoplasms } \\
(140-205)^{*}\end{array}$ & $\begin{array}{c}\text { Central Nervous System } \\
\text { Vascular Lesions } \\
(330-334)^{*}\end{array}$ & $\begin{array}{c}\text { Cardiovascular } \\
\text { Lesions } \\
(410-456)^{*}\end{array}$ & Other \\
\hline \multirow{8}{*}{ Donora } & \multirow{8}{*}{$1948-57$} & \multirow{8}{*}{1948} & \multirow{4}{*}{ Male } & $21-34$ & $\begin{array}{l}\text { Ill } \\
\text { Not III }\end{array}$ & $\begin{array}{l}187 \\
238 \\
\end{array}$ & - & - & $\begin{array}{c}1 \cdot 07 \\
-\end{array}$ & $\begin{array}{l}1 \cdot 60 \\
0 \cdot 84\end{array}$ \\
\hline & & & & $35-49$ & IIl & $\begin{array}{l}243 \\
166\end{array}$ & $\begin{array}{l}1.65 \\
0.60\end{array}$ & - & $\begin{array}{l}2 \cdot 47 \\
0 \cdot 60\end{array}$ & $\begin{array}{l}1 \cdot 23 \\
1 \cdot 81\end{array}$ \\
\hline & & & & $50-64$ & IIl $_{\text {Not IIl }}$ & $\begin{array}{l}266 \\
136\end{array}$ & $\begin{array}{l}3 \cdot 38 \\
3 \cdot 68\end{array}$ & $\begin{array}{l}1 \cdot 88 \\
2 \cdot 94\end{array}$ & $\begin{array}{l}7 \cdot 89 \\
7 \cdot 35\end{array}$ & $\begin{array}{l}7 \cdot 14 \\
1 \cdot 47\end{array}$ \\
\hline & & & & $\begin{array}{l}65 \text { and } \\
\text { Over }\end{array}$ & $\underset{\text { Not IIl }}{\text { IIl }}$ & $\begin{array}{r}100 \\
44\end{array}$ & $\begin{array}{l}7 \cdot 00 \\
6 \cdot 82\end{array}$ & $\begin{array}{r}7 \cdot 00 \\
15 \cdot 91\end{array}$ & $\begin{array}{l}30 \cdot 00 \\
15 \cdot 91\end{array}$ & $\begin{array}{l}7 \cdot 00 \\
6 \cdot 82\end{array}$ \\
\hline & & & \multirow{4}{*}{ Female } & $21-34$ & IIl $_{\text {Not IIl }}$ & $\begin{array}{l}240 \\
252\end{array}$ & $\overline{0 \cdot 40}$ & - & $\begin{array}{l}0.83 \\
0.40\end{array}$ & $\begin{array}{c}0.42 \\
-\end{array}$ \\
\hline & & & & $35-49$ & $\underset{\text { Not Ill }}{\text { Ill }}$ & $\begin{array}{l}232 \\
162\end{array}$ & $\begin{array}{l}1 \cdot 72 \\
1 \cdot 85\end{array}$ & $\begin{array}{l}0.86 \\
-\end{array}$ & $2 \cdot 59$ & $\begin{array}{l}1 \cdot 29 \\
0.62\end{array}$ \\
\hline & & & & $50-64$ & III $_{\text {Not III }}$ & $\begin{array}{l}193 \\
128\end{array}$ & $\begin{array}{l}4 \cdot 15 \\
0 \cdot 78\end{array}$ & $\begin{array}{l}1 \cdot 55 \\
0 \cdot 78\end{array}$ & $\begin{array}{l}8 \cdot 29 \\
5 \cdot 47\end{array}$ & $\begin{array}{l}3 \cdot 63 \\
3 \cdot 91\end{array}$ \\
\hline & & & & $\begin{array}{l}65 \text { and } \\
\text { Over }\end{array}$ & IIl & $\begin{array}{l}82 \\
43\end{array}$ & $\begin{array}{l}6 \cdot 10 \\
4 \cdot 65\end{array}$ & $\begin{array}{l}4 \cdot 88 \\
4 \cdot 65\end{array}$ & $\begin{array}{l}24 \cdot 39 \\
27 \cdot 91\end{array}$ & $\begin{array}{l}9 \cdot 76 \\
4 \cdot 65\end{array}$ \\
\hline \multirow{8}{*}{$\begin{array}{l} \\
\text { Arsenal } \\
\text { District }\end{array}$} & \multirow{8}{*}{$19 \overline{51-56}$} & \multirow{8}{*}{1951} & \multirow{4}{*}{ Male } & $21-34$ & IIl $_{\text {Not III }}$ & $\begin{array}{r}96 \\
846\end{array}$ & $\overline{0 \cdot 24}$ & - & $1 \cdot 04$ & $\begin{array}{l}1 \cdot 04 \\
1 \cdot 06\end{array}$ \\
\hline & & & & $35-49$ & $\underset{\text { Not III }}{\text { Ill }}$ & $\begin{array}{l}133 \\
862\end{array}$ & $\begin{array}{l}0.75 \\
0.35\end{array}$ & $\overline{0 \cdot 12}$ & $\begin{array}{l}2 \cdot 26 \\
1 \cdot 04\end{array}$ & $\begin{array}{l}1 \cdot 50 \\
0.46\end{array}$ \\
\hline & & & & $50-64$ & Not III $_{\text {III }}$ & $\begin{array}{l}133 \\
597\end{array}$ & $\begin{array}{l}4 \cdot 51 \\
2 \cdot 17\end{array}$ & $\begin{array}{l}0.75 \\
0.83\end{array}$ & $\begin{array}{r}10 \cdot 53 \\
4 \cdot 85\end{array}$ & $\begin{array}{l}5 \cdot 26 \\
1 \cdot 50\end{array}$ \\
\hline & & & & $\begin{array}{c}65 \text { and } \\
\text { Over }\end{array}$ & $\begin{array}{c}\text { Ill } \\
\text { Not Ill }\end{array}$ & $\begin{array}{l}100 \\
247\end{array}$ & $\begin{array}{l}7 \cdot 00 \\
1 \cdot 21\end{array}$ & $\begin{array}{l}7 \cdot 00 \\
3 \cdot 64\end{array}$ & $\begin{array}{l}15 \cdot 00 \\
14 \cdot 17\end{array}$ & $\begin{array}{r}10 \cdot 00 \\
4 \cdot 05\end{array}$ \\
\hline & & & \multirow{4}{*}{ Female } & $21-34$ & III & $\begin{array}{l}161 \\
901\end{array}$ & $\begin{array}{c}0.62 \\
-\end{array}$ & - & - & $1 \cdot 24$ \\
\hline & & & & $35-49$ & IIl $_{\text {Not III }}$ & $\begin{array}{l}213 \\
871\end{array}$ & $\begin{array}{l}1.41 \\
0.46\end{array}$ & $\begin{array}{l}0.94 \\
0.11\end{array}$ & $\begin{array}{l}1 \cdot 88 \\
0 \cdot 34\end{array}$ & $\begin{array}{l}1 \cdot 88 \\
0.23\end{array}$ \\
\hline & & & & $50-64$ & $\underset{\text { Not III }}{\text { III }}$ & $\begin{array}{l}187 \\
559\end{array}$ & $\begin{array}{l}0 \cdot 53 \\
1 \cdot 61\end{array}$ & $\begin{array}{l}1.07 \\
0.89\end{array}$ & $\begin{array}{l}3 \cdot 74 \\
2 \cdot 15\end{array}$ & $\begin{array}{l}2 \cdot 14 \\
0.89\end{array}$ \\
\hline & & & & $\begin{array}{l}65 \text { and } \\
\text { Over }\end{array}$ & Ill $_{\text {Not Ill }}$ & $\begin{array}{l}138 \\
261\end{array}$ & $\begin{array}{l}2 \cdot 17 \\
2 \cdot 68\end{array}$ & $\begin{array}{l}3 \cdot 62 \\
2 \cdot 68\end{array}$ & $\begin{array}{r}8 \cdot 70 \\
11 \cdot 11\end{array}$ & $\begin{array}{l}5 \cdot 07 \\
4 \cdot 21\end{array}$ \\
\hline
\end{tabular}

* Numbers in parenthesis refer to the International List of Causes of Death.

The same lack of consistency is observed in the Arsenal sample (Table I). Even where a degree of consistency is present, the differences in rates are frequently small in terms of their sampling error. Consequently, we can say only that the subsequent higher mortality of the ill persons in comparison with the not-ill persons is perhaps manifested by a higher mortality from cardiovascular diseases. However, for other causes of death, the ill groups also have a higher mortality than the not-ill at certain ages. In considering these findings, it must be remembered that the ill groups contain persons with all types of illness from acute upper respiratory infections to serious forms of heart disease. To arrive at an understanding of the meaning of the .higher mortality of persons reported ill, and the possible higher mortality from cardiovascular diseases, it is obviously necessary to examine in more detail the kinds of sicknesses reported by the ill group. This examination leads to the second question mentioned above.

(2) Sickness Class and Subsequent Mortality.Because of the limitations in the size of the sample, because individuals may have simultaneously several types of sickness, and because some account must be taken of variations in change of residence (as discussed in the paper cited), it is not feasible to make age-sex comparisons of mortality by illness classes. For this reason the following approach has been employed here. For the males and females of the total sample, separated into 5-year age groups, the percentages have been calculated of those who (a) died, $(b)$ changed their residence and remained alive, and $(c)$ retained their residence and remained alive during the intervals under study. These percentages are here regarded as the expectation that 
an individual of a specified sex-age class will be dead, will have moved and survived, or will have remained alive at the place of residence of the first survey. By summing up this expectation for the individuals in the group with a specified illness, we obtain the number of persons expected in each of these categories, i.e. expected on the basis of the experience of the total sample.

In Table II we compare for the several illness classes the observed and expected number of persons who moved and persons who died. With respect to change of residence, the data in Table II show that for both the Donora and the Arsenal samples there is little difference between the observed and expected numbers in any of the sickness status classes. The reported sickness at the time of the first survey, does not, therefore, seem to be related to any subsequent change of residence.

With respect to subsequent mortality, a rather interesting relationship is noted. In both the Donora and Arsenal samples the observed mortality is greater than or equal to the expected in every illness classification except "smog only" in both sexes in the Donora sample and the "remainder" category in females in the Arsenal sample. Most of the differences are small and only in the heart disease category are the differences between observed and expected numbers large enough to result in rejecting the hypothesis of equality at the 5 per cent. significance level.

TABLE II

RELATIONSHIP OF SICKNESS CLASS TO SUBSEQUENT MOVEMENT AND DEATH, BY SEX, OBSERVED AND EXPECTED

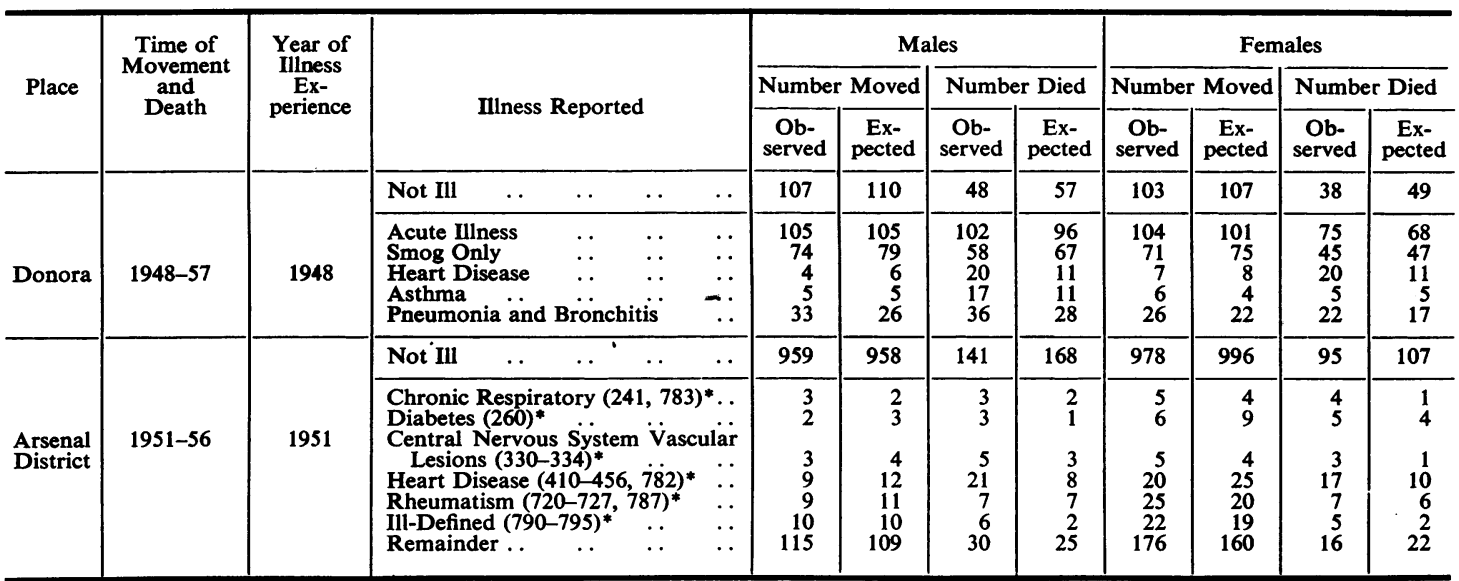

* Numbers in parenthesis refer to the International List of Causes of Death.

RELATIONSHIP OF REPORTED ILLNESS TO STATEP

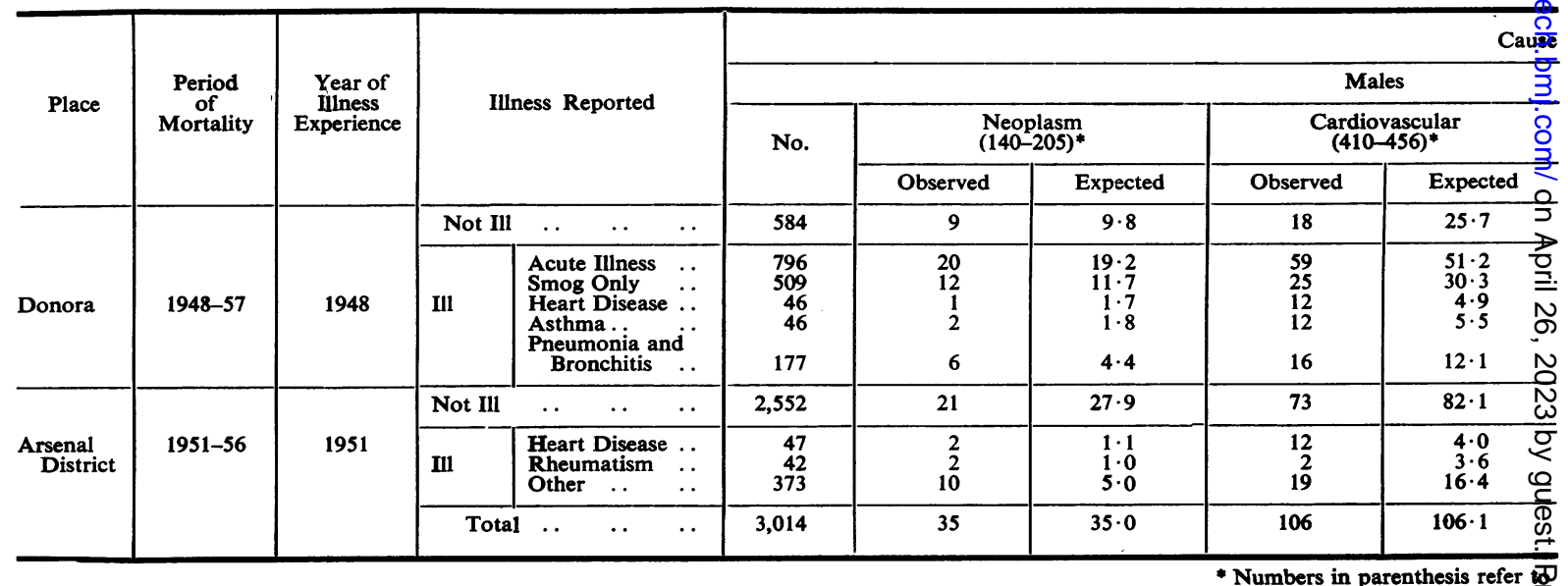


These findings would seem to indicate that the previously reported difference in subsequent mortality between the persons who were affected by the 1948 smog episode and those who were not affected is due, in large measure, to the inclusion in the affected group of a higher proportion of persons reported to have one or more of the specific diseases about which a direct query was made in 1948. In general, while the data suggest that the mortality has been higher in groups reporting illness at the time of the first survey, only for those reporting heart disease is there a marked difference. In view of these findings it is of interest to find an answer to the third question: to determine the extent to which the relationship between a complaint of heart disease and death from heart disease is manifest as would be anticipated.

(3) Specific Sickness and Cause of Death.-In calculating the expected mortality from specific causes of death, we have applied to persons in each age group who have reported a stated illness the appropriate cause-mortality rate of the total sample. Since the numbers become small, we have grouped the causes of death into only three categorles: neoplasm, heart disease, and "other". In the Arsenal sample we have grouped the sickness classes into: heart disease, rheumatism, and "other".

The observed and expected deaths from specific causes among persons in the specified sickness classes are shown in Table III. The data show that the higher mortality from heart disease among the ill group noted in Table $I$ is due, in the main, to a higher mortality among persons who complained of heart disease at the time of the first survey. In the
Donora sample, persons with asthma or pneumonia and bronchitis also experienced a higher mortality from heart disease, and the last-named group also from "other" causes of death. In the Arsenal sample, persons with "other" sickness also experienced a higher mortality from heart disease and from "other" causes of death, and the males alone from neoplasm. The sample is not sufficiently large to explore this last observation further.

\section{SUMMARY}

This is a report on the mortality experience of (a) a sample of 2,712 persons aged 21 years and over, resident in Donora, Pennsylvania, who were surveyed in 1948 to determine illness status with respect to the smog episode of that year and were re-surveyed in 1957; (b) a sample of 6,305 persons aged 21 years and over, resident in the Arsenal Health District, who were surveyed in 1951 to determine the presence or absence of sickness and for whom information on mortality up to 1956 was obtained.

In a previous paper it was reported that, in both samples, persons who claimed they were ill in the original survey died at a higher rate during the 8 and 5 year interval respectively before the second survey than persons who claimed no illness. Further? analysis of the relationship of the type of illness to cause of death is reported in this paper. The major findings of this analysis are:

(1) The ill groups had higher mortality from heart disease in most age-sex subdivisions.

(2) Persons who complained of heart disease had a higher mortality than others.

III

CAUSE OF DEATH, BY SEX, OBSERVED AND EXPECTED

\begin{tabular}{|c|c|c|c|c|c|c|c|c|}
\hline & & \multicolumn{7}{|c|}{ Females } \\
\hline \multicolumn{2}{|c|}{ Other } & \multirow[t]{2}{*}{ No. } & \multicolumn{2}{|c|}{$\begin{array}{l}\text { Neoplasm } \\
(140-205)^{*}\end{array}$} & \multicolumn{2}{|c|}{$\begin{array}{c}\text { Cardiovascular } \\
(410-456)^{*}\end{array}$} & \multicolumn{2}{|c|}{ Other } \\
\hline Observed & Expected & & Observed & Expected & Observed & Expected & Observed & Expected \\
\hline 21 & $22 \cdot 2$ & 585 & 7 & $9 \cdot 4$ & 20 & $24 \cdot 2$ & 11 & $14 \cdot 9$ \\
\hline $\begin{array}{r}43 \\
21 \\
7 \\
3\end{array}$ & $\begin{array}{r}41 \cdot 8 \\
25 \cdot 2 \\
3 \cdot 8 \\
4 \cdot 1\end{array}$ & $\begin{array}{r}747 \\
468 \\
72 \\
29\end{array}$ & $\begin{array}{r}17 \\
12 \\
1 \\
0\end{array}$ & $\begin{array}{r}14.6 \\
8.9 \\
1.8 \\
.8\end{array}$ & $\begin{array}{r}44 \\
22 \\
13 \\
4\end{array}$ & $\begin{array}{r}39.8 \\
24 \cdot 1 \\
5.4 \\
2.4\end{array}$ & $\begin{array}{r}28 \\
11 \\
6 \\
1\end{array}$ & $\begin{array}{r}24 \cdot 2 \\
14.7 \\
3 \cdot 2 \\
1.4\end{array}$ \\
\hline 12 & $9 \cdot 7$ & 146 & 3 & $3 \cdot 1$ & 13 & $8 \cdot 7$ & 11 & $5 \cdot 2$ \\
\hline 47 & $58 \cdot 6$ & 2,592 & 20 & $20 \cdot 5$ & 44 & $46 \cdot 7$ & 31 & $40 \cdot 6$ \\
\hline $\begin{array}{r}7 \\
3 \\
18\end{array}$ & $\begin{array}{r}2.6 \\
2.4 \\
11.3\end{array}$ & $\begin{array}{r}86 \\
67 \\
546\end{array}$ & $\begin{array}{l}0 \\
2 \\
6\end{array}$ & $\begin{array}{l}1.4 \\
1.0 \\
5.1\end{array}$ & $\begin{array}{r}11 \\
3 \\
9\end{array}$ & $\begin{array}{r}4 \cdot 3 \\
3 \cdot 1 \\
12.9\end{array}$ & $\begin{array}{r}6 \\
2 \\
18\end{array}$ & $\begin{array}{r}3 \cdot 3 \\
2.4 \\
10 \cdot 8\end{array}$ \\
\hline 75 & $74 \cdot 9$ & 3,291 & 28 & $28 \cdot 0$ & 67 & $67 \cdot 1$ & 57 & $57 \cdot 1$ \\
\hline
\end{tabular}

International List of Causes of Death. 
(3) Persons who complained of heart disease died more often from heart disease, and those who complained of certain other conditions died more often from other causes of death.

These findings point to the value of information obtained from household surveys as a means of recognizing persons with a relatively higher risk of mortality. At least for the complaints classified as heart disease, the higher risk of dying and of dying from heart disease is apparent in the two samples. For other complaints and their possible relationship with other causes of death, more observations are required. Further analysis of the available informa- tion on these samples is also required to learn about the duration of the higher risk of mortality for the persons ill. These findings lead also to the general consideration that, if the survey of the type undertaken in Donora and the Arsenal does in fact indicate persons with higher risk of mortality from specific causes, such surveys can be used as a means for exploring more effectively the antecedent factors of the causes of death.

\section{REFERENCE}

Thompson, D. J., and Ciocco, A. (1958), Brit. J. prev. soc. Med., 12 , 182. 